\title{
New Designs in Historic Context: Starchitecture vs Architectural Conservation Principles
}

\author{
Damla Misırlisoy \\ Department of Architecture, Girne American University, Kyrenia, Northern Cyprus, (via Mersin 10 Turkey)
}

Copyright@2017 by authors, all rights reserved. Authors agree that this article remains permanently open access under the terms of the Creative Commons Attribution License 4.0 International License

\begin{abstract}
The design approach of new additions is one of the most commonly discussed issues in the conservation field. Additions should be differentiated but compatible for achieving a harmony between new and old. Heritage buildings can be transformed into major landmarks of the city after conversions or may harm the originality and significance of the heritage buildings. Although there are international preservation standard and charters that introduce principles for interventions in historical context, they are not followed by some countries. Local authorities give permission to new developments that have been designed by Star architects, which can be inappropriate to historical context, to promote the district and the country. The paper questions the success of the selected designs by star architects in terms of architectural conservation principles that defined in the international preservation standards and charters. Selected case studies have been assessed through the identified principles from the selected international preservation standards and charters. New designs in historic environments should add another value to the heritage buildings rather than destroying its character and identity. The additions can be acceptable if it contributes to the city identity and if it does not damage the identity of the existing historic structure.
\end{abstract}

Keywords Star Architects, Additions, Heritage Buildings, Conservation Principles

\section{Introduction}

Most buildings will change their use through their lifetime; this will invariably necessitate changes to the internal layout and fabric of the old building. However, the appropriateness of the new use to the building fabric and its integrity does need to be considered [1]. Interventions that applied should work with the existing building, instead of being against it. Appropriate materials must be used where new additions are needed. New addition can be designed either in a harmony or in contrast to the existing and the approach is identified depending on the designer [2]. As Schittich[3] states: "Working with the given fabric, which imposes necessary constraints on the designer, is one of the most creative and fascinating tasks in architecture." As the simple reason, conversion is a cheaper and less complicated process than constructing a new building. On the other hand, the new interest in adaptive reuse makes unknown buildings transformed into major landmarks with contemporary additions [4].

Cities, especially the ones in Europe, apply the concept and techniques of city branding as a strategy for place marketing [5]. The satisfaction of locals and tourists are strongly influenced by the image of a city or district that iconic buildings and their effect on city branding have a great contribution [6]. New designs in historic contexts are used as city branding and place marketing with the interventions by Star architects in various countries.

Additions have always been a common type of intervention to heritage buildings when they no longer meet the current space needs [7]. However, the interventions should be kept to the minimum level in order not to harm the originality of the heritage building. A new addition to a heritage building includes the problem of establishing an appropriate relation between traditional and contemporary architectural language [8].

An addition can help to transform a disused or abandoned heritage building to a major landmark, which acts as city branding. Remodelling is a worthy challenge since having different historic layers on top of each other makes the building unique in terms of identity [9]. Giving new life to old buildings is a worthy challenge [10] since transformation of heritage buildings into major landmarks with necessary additions may contribute to the city identity. However, interventions applied should be considered in terms of conservation principles.

The old and new can be contrasting or harmonious but in each case the new addition have to be separated from the old ones with a different identity in order to see the difference between old and new. The relation between the historical 
buildings with the additions is so important that the new extensions have to be appropriate in terms of material selection, connection details and structure system.

The new additions have to be separated from the old ones that can be removed any time without destroying the original building [9].

Preserving the qualities of the heritage building and being respectful to the existing building is crucial in terms of contemporary conservation concept. Although there are international preservation standard and charters that introduce principles for interventions in historical context, they are not followed by some countries. Local authorities give permission to new additions that have been designed by Star architects, which can be inappropriate to the historical context, in order to promote the district and the city. The paper questions the success of the selected addition designs in historical context by star architects through the international preservation standard and charters. Selected case studies have been critically assessed in terms of the conservation principles that defined in the mentioned standards and charters.

\section{Methodology}

The design approach of new additions in the historic context is one of the most commonly discussed issues in the conservation field. The aim of the research is to examine the success of the selected additions in historical context that has been designed by star architects, through architectural conservation principles. Literature survey has been done in order to define these principles on the selected international preservation standards and charters that include principles for new designs in historic context. The selection of the standards has been done according to the significance of the standards and charters. Most significant ones within the field of new designs in historic context have been selected for surveying. Then, selected case studies have been critically assessed in terms of the conservation principles that defined from the selected international preservation standards and charters. The case studies have been selected according to the criteria defined below:

- Selected examples are mainly from the Central Europe; especially, from the countries that many examples of contemporary additions in the historic context.

- They are designed by a Star architect (including Zaha Hadid, Norman Foster, Coop Mimmelb(l)au, Jean Nouvel, Herzog \& De Meuron).

- $\quad$ The new additions are contemporary examples.

- $\quad$ New designs have different approaches (contrasting and harmony) in order to discuss different aspects.

Selected 5 case studies that include an addition have been critically assessed according to the defined principles and then, compared.

\section{Definition of 'Starchitecture'}

In architecture, the building itself can be accepted as a brand, a landmark for the community and as a tool for promotion. Also sometimes the architect can be seen as a brand with the identified concepts and forms, which can be called as star architects. Starchitects become famous with a particular "signature" design with particular forms. After the 2008 world economic crisis lesson, public opinion questions how our buildings perform socially, environmentally and economically in sustainability terms. On the other hand, there is a trend to use the design of star architects as a city branding and promotion to attract people. Frank Gehry and his curved surfaces, Daniel Libeskind and his angular forms, the late Zaha Hadid and hers fluid volumes are examples of brands with a focus on creating easily identifiable shapes. Peter Zumthor or Norman Foster instead are emphasizing on idea conveying, formulating and communicating the message of the personal brand, being on the ideological stance of celebrity [11].

Starchitects are in the same time transmitters of valuable concepts and creators of recognizable forms with landmark potential. The public interest sustained by the media can invest a building with the brand. Buildings becoming landmarks a community, regional and also national level are usually designed by famous architects with a few Pritzker prize winners, such as Rem Koolhaas, Philippe Starck, Zaha Hadid, Norman Foster, Jean Nouvel or Renzo Piano [11].

The emphasis of the star architecture is on the symbolic role played by spectacular buildings. The most important issue in the discussions is the importance of the structure is not in its functionality but rather in its contribution to marketing the city. The local and planning authorities give permission to these interventions by ignoring international and local preservation standards and charters since these iconic buildings become part of a city's brand like in the example of Louvre Pyramid in Paris. The success of the intervention is still one of the discussions topics in the conservation field but there is a fact that the Pyramid attracts one million tourists every day from all around the world to the museum.

\section{Conservation Principles for New Designs in Historic Context}

Preserving the qualities of the heritage building and being respectful to the existing is important in addition design [12]. Additions to heritage buildings are one of the most important issues in architectural conservation since there are many discussions on the proper approach of new additions in historical context [7]. A new addition should preserve significant materials, features and the historic character [13]. Addition design can be more complicated than a new design since existing structure brings design limitations of working. There are also problems such as planning, legal and 
structural issues that should be taken into account. Circulation, access, structural integrity and choice of materials should also be considered. It is hard to define universal characteristics of an appropriate addition since it varies according to the existing structure. Simply, an appropriate addition should revitalize and enrich the existing building. It should work as the part of the whole composition rather than a single project attached to the existing building [14]. There are different types also in the location of the new addition to the whole composition. In the commonest cases, additions stand beside the predecessor buildings or sometimes stand on top of them [15].

Before the proposal for the new addition, heritage values of the existing building should be clearly investigated and identified. Instead of proposing a form to the heritage building, a new addition should complement and contribute to the sense of proportion, disposition and historical pattern [8]. While the standards do not call for new additions to be contrasting in character or require them to be in a contemporary style, they do require new construction to be "differentiated" without defining how, by whom, or to what degree, and to be "compatible" without offering criteria for achieving a harmonious relationship. The standards do not suggest where the balance between "differentiation" and “compatibility” should be placed [16].

The new addition should be differentiated from the old and should also be compatible; however the solutions are based on the creativity of the designer. The old and new can be contrasting or harmonious; however, for both the new addition should be separated from the existing to be able to perceive the difference [9].

The new addition should respect the history of the buildings in order to be an appropriate intervention. It should also respect the original building in terms of form, size and proportion. The addition should also be investigated on a larger scale in terms of its relation to the context and close neighbourhood. The effect of the addition to the social benefits to the district and also the contribution to the local economy should be questioned.

As Carbonara [17] states there are three fundamental components of restoration: a) the history of architecture and theory of restoration; b) the techniques of survey, analysis, diagnosis and interventions on the materials and the structure; c) legislative and regulatory aspects. Every city and country has its own legislative and regulatory aspects regarding with the conservation and restoration of heritage buildings. Thus, in order to create common regulatory aspects there are international preservation standards and charters. In this study, some of them has been selected and surveyed in terms of the principles that they include for the new designs in historic context.

Selected international preservation standards and charters are Venice Charter [18], Resolutions of the symposium on the introduction of contemporary architecture into ancient groups of buildings [19], Recommendation concerning the safeguarding and contemporary role of historic areas [20], Burra Charter [21] and Vienna Momerandum [22], which are the ones that include conservation principles regarding with the designing in the historic environment. Literature survey has been done through mentioned charters and conservation principles have been defined in Table 1.

\section{Critical Assessment of the Selected Case Studies through Defined Conservation Principles}

Five case studies that have been designed by Star architects have been selected as the case study of the research. All of the selected case studies are located in the Europe and the designers of the new additions are known architects (Table 2). The selected case studies have been assessed in terms of conservation principles that have been defined in Table 3. 
Table 1. Conservation principles that identified in the international preservation standards and charters

\begin{tabular}{|c|c|}
\hline \multicolumn{2}{|r|}{ ARCHITECTURAL CONSERVATION PRINCIPLES FOR NEW DESIGN IN HISTORIC CONTEXT } \\
\hline \multicolumn{2}{|r|}{ VENICE CHARTER, 1964} \\
\hline Article 12. & $\begin{array}{l}\text { Replacements of missing parts must integrate harmoniously with the whole, but at the same time must be } \\
\text { distinguishable from the original so that restoration does not falsify the artistic or historic evidence. }\end{array}$ \\
\hline Article 13. & $\begin{array}{l}\text { Additions cannot be allowed except in so far as they do not detract from the interesting parts of the building, its } \\
\text { traditional setting, the balance of its composition and its relation with its surroundings. }\end{array}$ \\
\hline \multicolumn{2}{|c|}{$\begin{array}{l}\text { RESOLUTIONS OF THE SYMPOSIUM ON THE INTRODUCTION OF CONTEMPORARY ARCHITECTURE INTO ANCIENT GROUPS OF } \\
\text { BUILDINGS, } 1972\end{array}$} \\
\hline Article 2. & $\begin{array}{l}\text { Such contemporary architecture, making deliberate use of present-day techniques and materials, will fit itself into an } \\
\text { ancient setting without affecting the structural and aesthetic qualities of the latter only in so far as due allowance is } \\
\text { made for the appropriate use of mass, scale, rhythm and appearance. }\end{array}$ \\
\hline Article 3. & $\begin{array}{l}\text { The authenticity of historical monuments or groups of buildings must be taken as a basic criterion and there must be } \\
\text { avoidance of any imitations, which would affect their artistic and historical value. }\end{array}$ \\
\hline \multicolumn{2}{|c|}{ RECOMMENDATION CONCERNING THE SAFEGUARDING AND CONTEMPORARY ROLE OF HISTORIC AREAS, 1976} \\
\hline Article 24. & $\begin{array}{l}\text { Where safeguarding plans exist urban development or slum clearance programmes consisting of the demolition of } \\
\text { buildings of no architectural or historic interest and which are structurally too unsound to be kept, the removal of } \\
\text { extensions and additional storeys of no value, and sometimes even the demolition of recent buildings which break the } \\
\text { unity of the area, may only be authorized in conformity with the plan. }\end{array}$ \\
\hline Article 28. & $\begin{array}{l}\text { Particular care should be devoted to regulations for and control over new buildings so as to ensure that their architecture } \\
\text { adapts harmoniously to the spatial organization and setting of the groups of historic buildings. To this end, an analysis } \\
\text { of the urban context should precede any new construction not only so as to define the general character of the group of } \\
\text { buildings but also to analyse its dominant features, e.g. the harmony of heights, colours, materials and forms, constants } \\
\text { in the way the facades and roofs are built, the relationship between the volume of buildings and the spatial volume, as } \\
\text { well as their average proportions and their position. Particular attention should be given to the size of the lots since there } \\
\text { is a danger that any reorganization of the lots may cause a change of mass, which could be deleterious to the harmony of } \\
\text { the whole. }\end{array}$ \\
\hline \multicolumn{2}{|r|}{ BURRA CHARTER, 1999} \\
\hline Article 15.2 & $\begin{array}{l}\text { Changes, which reduce cultural significance, should be reversible, and be reversed when circumstances permit. } \\
\text { Reversible changes should be considered temporary. Non-reversible change should only be used as a last resort and } \\
\text { should not prevent future conservation action. }\end{array}$ \\
\hline Article 22.1 & $\begin{array}{l}\text { New work such as additions to the place may be acceptable where it does not distort or obscure the cultural significance } \\
\text { of the place, or detract from its interpretation and appreciation. New work may be sympathetic if its siting, bulk, form, } \\
\text { scale, character, colour, texture and material are similar to the existing fabric, but imitation should be avoided. }\end{array}$ \\
\hline Article 22.2 & New work should be readily identifiable as such. \\
\hline \multicolumn{2}{|r|}{ VIENNA MOMERANDUM, 2005} \\
\hline Article 18. & $\begin{array}{l}\text { Decision-making for interventions and contemporary architecture in a historic urban landscape demand careful } \\
\text { consideration, a culturally and historic sensitive approach, stakeholder consultations and expert know-how. Such a } \\
\text { process allows for adequate and proper action for individual cases, examining the spatial context between old and new, } \\
\text { while respecting the authenticity and integrity of historic fabric and building stock. }\end{array}$ \\
\hline Article 26. & $\begin{array}{l}\text { As a general principle, proportion and design must fit into the particular type of historic pattern and architecture, while } \\
\text { removing the core of building stock worthy of protection ("façadism") does not constitute an appropriate mean of } \\
\text { structural intervention. Special care should be taken to ensure that the development of contemporary architecture in } \\
\text { World Heritage cities is complementary to values of the historic urban landscape and remains within limits in order not } \\
\text { to compromise the historic nature of the city. }\end{array}$ \\
\hline
\end{tabular}


Table 2. Selected case studies

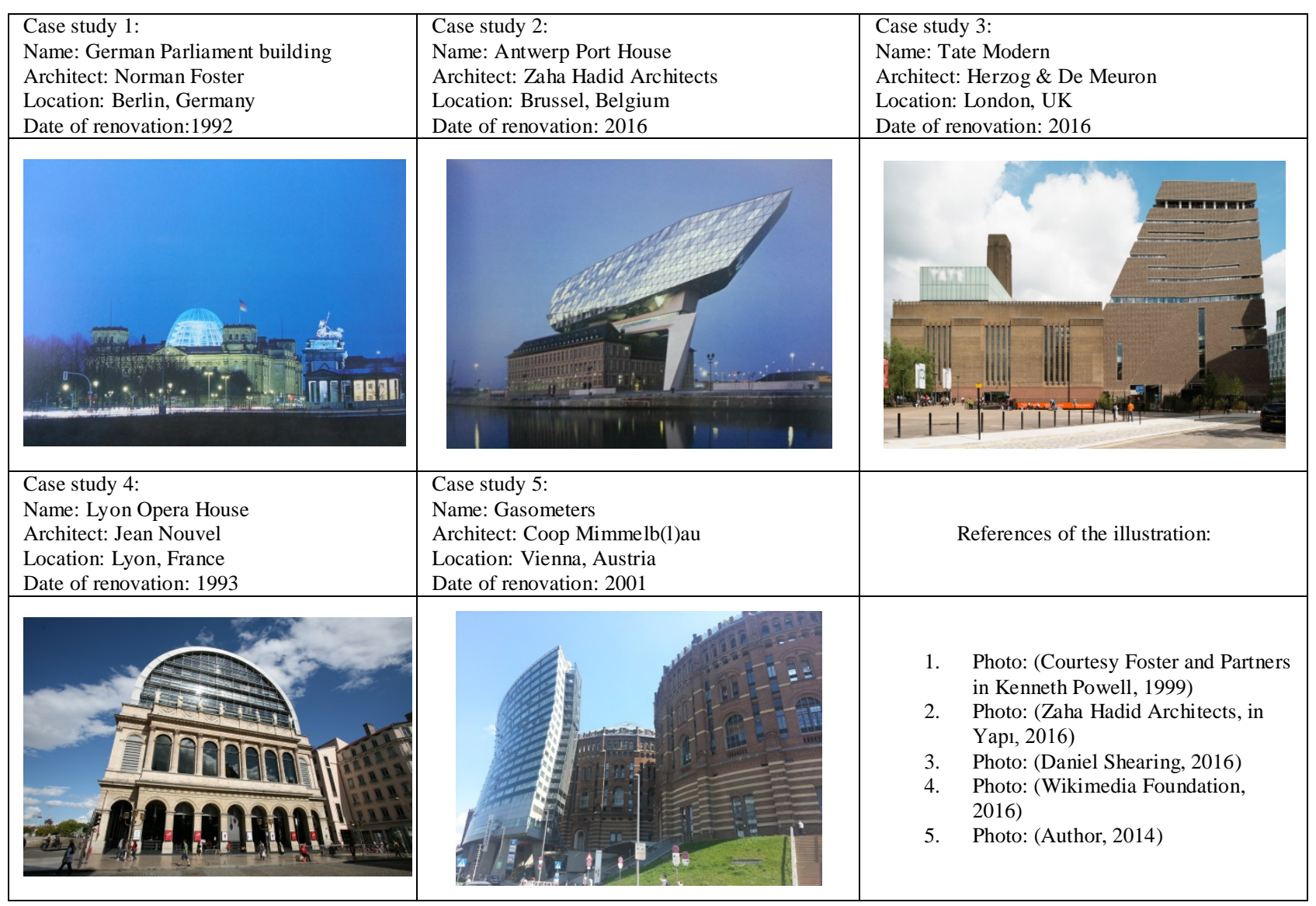

The building was severely damaged by a fire and then fell into disuse after World War II. A full restoration made, when the building underwent a reconstruction led by architect Norman Foster. The main damaged part of the building was the dome in the centre of the building. While some parts have been reconstructed, the decision has been taken by the architect to design a dome with a contemporary approach in terms of materials and construction techniques. The decision is appropriate in terms of not to cause a misunderstanding in terms of original and addition parts.

The large glass dome at the top of the Reichstag has a 360-degree view of the city and its surrounding. The main hall of the parliament below can also be seen from inside the dome, which symbolizes a kind of transparency in the politics of the government. The aim of the glass dome is also to take natural sunlight into the parliament hall.

The new addition respects the history of the buildings since it has a concept behind and symbolizes the transparency of the government in terms of politics. It also respects the original building in terms of form, size and proportion. There is a contrasting approach in terms of material choice and style and the addition is distinguishable from the original. Since the dome is transparent, it is not over dominating the existing building. Instead of devaluing the heritage building, it is adding another layer to the building with the new interpretation. New addition respects the authenticity and integrity of historic fabric and building stock. After the new intervention by the architect, the building has become one of the most important attraction points of the city. The building became a social gathering place since they come to visit the dome and also have a sightseeing of the whole city.

On the other hand, Zaha Hadid has a totally different approach in the extension for the Antwerp Port House. The existing building was a fire station building and converted into administration office for the port. Since the port is the second largest port in Europe, the capacity of the existing fire station building was not enough for the space requirements of the new function, they decided to organize a competition for the new extension of the port house. The building is completed in 2016 and the design of the Zaha Hadid Architects as the winner of the contest.

The new addition is over dominating the existing building in terms of its height and proportion with the old and there is no respect to the history of the original context. The new addition is so bulky and huge and also out of human scale. According to the principles in the international preservation standards and charters, new addition should be appropriate in terms of mass, scale, rhythm and proportion. New work may be sympathetic if its form, scale, character, colour, texture and material are similar to the existing fabric. In this case study, it does not have any relation neither with the building 
that it is located on top nor with the context and close neighbourhood. On the other hand, the addition is distinguishable from the existing. There is avoidance of any imitation of the existing and new addition is reversible.

Tate Modern's transformation includes two phases that both are designed by Herzog \& De Meuron. The first intervention was in 2000 when the building is opened as an art gallery. Then, the second intervention was in 2016, which was aimed to extend the exhibition spaces.

The first proposal for the extension of exhibition spaces was designed cubes on top of each other that some of them were projected out in a dynamic way. However, the proposal had been rejected since it is discussed that it is contrasting and does not have any relation with the existing building. Then the designers have kept the same form and changed the cladding materials and the openings on the facades. They tried to use the same material with the existing industrial building in order to have harmony between new and the old. Proportion of the openings on the façade has also been inspired from existing facade. Although they tried to use some references from the existing building, the new addition is over dominating the existing one in terms of height and proportion.

The first intervention was mainly a roof top addition on the building as a café and some other minor intervention in the inner environment to adapt the building to the art gallery function. The roof addition is more successful in terms of appropriateness to the existing building when compared with the second extension. It is taking references from the existing building in terms of form. The new and old is compatible with each other in terms proportion. Although they are contrasting in terms of materials and colours, they are in unity and harmony with the context and close surrounding.

Lyon Opera House consists of a roof top addition to creating a new dance hall. Jean Nouvel designs the new addition and the form of the addition takes the inspiration from the arches on the façade. The design is successful in term of taking some reference points from the existing building. The new addition has harmonious integration with the whole. It is appropriate in terms of form, rhythm, colour and proportion. However, the compatibility of the addition should be questioned in the city context and close surrounding. The building is located in the city centre, in a historical context and the height of the addition is exaggerated when compared with the existing historical buildings in the close neighbourhood. Interventions are reversible and can be reversed when circumstances permit. New addition respects the authenticity and integrity of historic fabric and building stock.

Vienna's four historic Gasometer buildings constructed by Emperor Franz Joseph in the late nineteenth century in the industrial zone, originally housed the tanks for the municipal gas supply [23]. The Gasometers were converted to retail and commercial units that answer all the basic needs of the dwellers. They were four cylindrical gas containers that are enclosed with red brick façade. Gasometers are one of the most interesting examples of adaptive reuse and remodelling. The structures were gutted during remodelling and only the red brick façade and the steel roof was left as it is. The idea of expanding the building was to increase the number of housing and office units. The extension covers the front facade of the building since the old structure is not visible when passing from the main road.

There is no balance between the existing structure and the new extension. New addition does not respect the authenticity and integrity of historic fabric and building stock. And also is does not fit itself into an ancient setting without affecting the aesthetic qualities of the latter. The success of the project is that the new additions are freestanding structures and do not touch to the existing walls. They are also removable when it is needed without any harm the originality of the structures.

The contribution of the reuse to the environment and the community is also important since there is always an interaction between the conversion projects and the environment. Adaptive reuse of a heritage building can be a catalyst for the other projects in the close surroundings. The project is also successful in terms of creating a new life out of the city centre. It caused regeneration of the whole area and to an increase in land value. 
Table 3. Assessment of selected case studies through international preservation standards and charters

\begin{tabular}{|c|c|c|c|c|c|}
\hline Architectural conservation principles from international preservation standards and charters & $\begin{array}{c}\text { Case } \\
\text { study } 1\end{array}$ & $\begin{array}{c}\text { Case } \\
\text { study } 2\end{array}$ & $\begin{array}{c}\text { Case } \\
\text { study } 3\end{array}$ & $\begin{array}{c}\text { Case } \\
\text { study } 4\end{array}$ & $\begin{array}{c}\text { Case } \\
\text { study } 5\end{array}$ \\
\hline 1. New addition should have harmonious integration with the whole. & $\checkmark$ & $\checkmark$ & $\checkmark$ & $\checkmark$ & \\
\hline $\begin{array}{l}\text { 2. Additions must be distinguishable from the original so that restoration does not falsify the } \\
\text { artistic or historic evidence. }\end{array}$ & $\checkmark$ & & $\checkmark$ & $\checkmark$ & $\checkmark$ \\
\hline 3. Additions should not devalue the heritage building and its traditional settings. & $\checkmark$ & & & & \\
\hline 4. New addition should be in harmony between the close surroundings. & $\checkmark$ & & & & \\
\hline 5. There should be a balance in composition of old and new. & $\checkmark$ & & & & \\
\hline $\begin{array}{l}\text { 6. New addition should be appropriate in terms of mass, scale, rhythm and proportion. New } \\
\text { work may be sympathetic if its form, scale, character, colour, texture and material are similar } \\
\text { to the existing fabric. }\end{array}$ & $\checkmark$ & & $\checkmark$ & & $\checkmark$ \\
\hline $\begin{array}{l}\text { 7. Contemporary addition should fit itself into an ancient setting without affecting the } \\
\text { structural and aesthetic qualities of the latter. }\end{array}$ & $\checkmark$ & & & $\checkmark$ & \\
\hline $\begin{array}{l}\text { 8. There must be avoidance of any imitations, which would affect their artistic and historical } \\
\text { value. }\end{array}$ & $\checkmark$ & $\checkmark$ & $\checkmark$ & $\checkmark$ & $\checkmark$ \\
\hline $\begin{array}{l}\text { 9. Changes, which reduce cultural significance, should be reversible, and be reversed when } \\
\text { circumstances permit. }\end{array}$ & $\checkmark$ & $\checkmark$ & $\checkmark$ & $\checkmark$ & $\checkmark$ \\
\hline $\begin{array}{l}\text { 10. New additions should respect the authenticity and integrity of historic fabric and building } \\
\text { stock. }\end{array}$ & $\checkmark$ & & $\checkmark$ & $\checkmark$ & \\
\hline
\end{tabular}

According to the table, the most successful addition is the German Parliament building by Norman Foster since the intervention respects all the discussed aspects. On the other hand, the addition to the Antwerp Port House by Zaha Hadid has been found the most inappropriate addition in terms of principles defined in the international preservation standards and charters.

\section{Conclusions}

Designing in the historic context is one of the most challenging tasks in the field since it is not easy to catch the harmony between new and the old. On the other hand, having different layers on a single building makes buildings unique and charming in terms of identity. Generally, it is agreed in the research that additions should reflect the date that they are built in terms of innovation, technology and material. When reflecting its own era, compatibility between the old and new must be shown. New interventions should preserve the originality of the historic context and should be respectful to it. Appropriateness of the new designs in the historic context is an important issue in the conservation field since there are many different approaches and discussions.

Visually attractive buildings play a major role in promoting the city identity. These buildings can be influenced the city and building itself identity either positively or negatively. In order to judge the appropriateness of a new design in the historic context, there are international preservation standards and charters that can be guide designers and decision makers. The new designs in historic context can be acceptable if it contributes to the city identity and if it does not damage the identity of the existing historic structure. The buildings are seen as a political and symbolic interests and promotion of the city by local and planning authorities but at the same time, the interventions should respect the originality of the heritage buildings and its close neighbourhood.

Unfortunately, there is a gap between legislative issues and architectural conservation principles in the field of new designs in historic context. Although there are international preservation standard and charters that introduce principles for interventions in historical context, they are not followed by some countries. Local authorities give permission to new developments that have been designed by Star architects, which can be inappropriate to historical context, to promote the district and the country.

The paper determines the assessment criteria for new designs in the historic context and creates a reference for the designers who work on existing fabric. The significance of this study is to guide designers that on interventions and new designs in historic context. Additionally, this method can be used for local authorities to judge the projects. The main goal of the research is to raise the awareness of the issue of new designs to historic context and prepare a base for the other researchers to develop this study further as a guideline.

\section{REFERENCES}

[1] A. Orbaşl1, Architectural Conservation, Blackwell Publishing, London, 2008.

[2] D. Latham, Creative reuse of buildings, Donhead Publishing, London, 2000.

[3] C. Schittich, In Detail Building in Existing Fabric, Birkhauser. Berlin, 2003.

[4] K. Powell, Architecture Reborn, Laurence King Publishing, London, 1999.

[5] M. Kavaratzis and G. J. Ashworth, City branding: an effective assertion of identity or a transitory marketing trick?, Blackwell Publishing, Oxford, 2005. 
[6] M. Riza, N. Doratli, A review on the design of new buildings in historic settings: Harmonious integration. Germany: VDM, 2011.

[7] Z.N.G. Torres, Historic buildings and contemporary additions: the elements of a cohesive design relationship. Unpublished Master Thesis. University of Maryland. Maryland, 2009.

[8] H. Yüceer, B. İpekoğlu, An architectural assessment method for new exterior additions to historic buildings, Journal of Cultural Heritage, 13 (4), 419-425, 2012.

[9] D. Misirlisoy, Contemporary extensions and heritage buildings: A design methodology, Lambert Academic Publishing, Germany, 2016.

[10] P. Jodidio, 100 great extensions and renovations, Images Publishing, Australia, 2007.

[11] R. L. Niculae, Between Responsibility and Starchitecture, Review of Applied Socio- Economic Research, 11(1): pp. 67, 2016.

[12] D. Misırlısoy, K. Günçe, An analytical approach for evaluation of contemporary additions to historic buildings: Case of Kadir Has University, RE-COND'15: 'Re-evaluating contemporary designs in historical context' 22-24 July 2015, Istanbul, Turkey, 2015.

[13] A.E Grimmer and K.D Week, Preservation brief 14: New exterior additions to historic buildings: preservation concerns, Technical Preservation Services, National Park Service, U.S. Department of the Interior. Washington. D.C. Online available from: http://www.nps.gov, 2012.
[14] A. Mornement, Extensions, Laurence King Publishing, London, 2007.

[15] P.S. Byard, The architecture of additions: design and regulations, W. W. Norton \& Company, London, 2005.

[16] S.W. Stewen, Differentiated and compatible. Online available from: http://www.traditionalbuilding.com, 2009.

[17] G. Carbonara, Some reflections from the Italian perspective on architectural restoration, in conserving the authentic: essays in honour of Jukka Jokilehto, ICCROM Publishing, Rome, 2009.

[18] ICOMOS, Venice Charter, International charter for the conservation and restoration of monuments and sites, Online available from: http://www.icomos.org, 1964.

[19] ICOMOS, Resolutions of the symposium on the introduction of contemporary architecture into ancient groups of buildings, Online available from: http://www.icomos.org, 1972.

[20] UNESCO, Recommendation concerning the safeguarding and contemporary role of historic areas, Online available from: http://www.unesco.org, 1976.

[21] ICOMOS, Burra Charter, The Charter for Places of Cultural Significance, Online available from: http://australia.icomos.org, 1999.

[22] UNESCO, Vienna Momerandum on World heritage and contemporary architecture- managing the historic urban landscape, Online available from: http://www.unesco.org, 2003.

[23] R. Klanten, and L. Feireiss, Build-on: Converted architecture and transformed buildings, Gestalten, Berlin, 2009. 